IZA DP No. 7685

Engaging in Corruption:

The Influence of Cultural Values and Contagion Effects at the Micro Level

Wang-Sheng Lee

Cahit Guven

October 2013 


\title{
Engaging in Corruption: The Influence of Cultural Values and Contagion Effects at the Micro Level
}

\author{
Wang-Sheng Lee \\ Deakin University \\ and IZA \\ Cahit Guven \\ Deakin University
}

\section{Discussion Paper No. 7685 \\ October 2013}

\author{
IZA \\ P.O. Box 7240 \\ 53072 Bonn \\ Germany \\ Phone: +49-228-3894-0 \\ Fax: +49-228-3894-180 \\ E-mail: iza@iza.org
}

\begin{abstract}
Any opinions expressed here are those of the author(s) and not those of IZA. Research published in this series may include views on policy, but the institute itself takes no institutional policy positions. The IZA research network is committed to the IZA Guiding Principles of Research Integrity.

The Institute for the Study of Labor (IZA) in Bonn is a local and virtual international research center and a place of communication between science, politics and business. IZA is an independent nonprofit organization supported by Deutsche Post Foundation. The center is associated with the University of Bonn and offers a stimulating research environment through its international network, workshops and conferences, data service, project support, research visits and doctoral program. IZA engages in (i) original and internationally competitive research in all fields of labor economics, (ii) development of policy concepts, and (iii) dissemination of research results and concepts to the interested public.
\end{abstract}

IZA Discussion Papers often represent preliminary work and are circulated to encourage discussion. Citation of such a paper should account for its provisional character. A revised version may be available directly from the author. 


\section{ABSTRACT \\ Engaging in Corruption: The Influence of Cultural Values and Contagion Effects at the Micro Level ${ }^{\star}$}

Previous empirical work on corruption has generally been cross-country in nature and focused on utilizing country-level corruption ratings. By using micro-level data for over 20 European countries that directly measure individual characteristics, corruption experiences, gender roles, trust and values to examine the determinants of corruption, this paper goes beyond the search for associations between various macro factors and perceptions of corruption that is prevalent in the economic literature. One focus of the paper is on how cultural norms such as gender roles and risk preferences influence corruption and whether there are gender differences in the determinants of corruption. In addition, this paper also seeks to determine if there are contagion effects in corruption at the micro level. Using a seemingly unrelated probit approach, this paper provides empirical estimates of how past experiences with corruption affects both how bribery is viewed and the actual act of offering a bribe.

JEL Classification: K420, O170

Keywords: corruption, gender roles, risk preference, seemingly unrelated probit

Corresponding author:

Wang-Sheng Lee

Deakin University

School of Accounting, Economics and Finance

70 Elgar Road

Burwood, VIC 3125

Australia

E-mail: wang.lee@deakin.edu.au

\footnotetext{
"We would like to thank seminar participants at Deakin University and Monash University for providing feedback on an earlier version of the paper. We are also grateful to Ananish Chaudhuri and two anonymous referees for helpful comments.
} 


\section{Introduction}

Corruption is a prevalent worldwide problem that has existed across various cultures for centuries. At present, the extent of the problem worldwide is so substantial that the General Assembly of the United Nations in 2003 decided to designate 9 December as 'International AntiCorruption Day' in order to raise the awareness of corruption and help reduce its incidence. Economists often define corruption as the 'misuse of public office for private gain' (Svensson, 2005) or the 'breaking of a rule by a bureaucrat (or an elected official) for private gain' (Banerjee et al., 2012). In this paper, we focus on bribery, just one crude and specific form of corruption. In particular, we look at three bribery outcomes: offering a bribe, accepting a bribe and the overall tolerance of bribe giving and accepting. According to the World Bank Institute, more than one trillion dollars were paid in bribes based on 2001-02 economic data.

A primary challenge facing empirical research on corruption is one of measurement. As perceived corruption ratings at the country level produced by Transparency International (TI), the World Bank (WB), and the business consultancy Political Risk Services, which publishes the International Country Risk Guide (ICRG) are easily available, until recently, the dominant approach to addressing corruption in the empirical approach has been to estimate some form of a cross-country regression. For example, since Mauro (1995) highlighted the link between corruption and economic growth, many studies in economics have focused on examining the macro effects of corruption and why some countries' governments were perceived to be more corrupt than others. Lambsdorff (2006) and Treisman (2007) provide useful overviews of this vast literature. In general, the literature has found that perceived corruption is lower in developed economies with established liberal democracies (e.g., Treisman, 2000), fiscal decentralization (e.g., Fisman and Gatti, 2002), with a free and widely read press (e.g., Brunetti and Weder, 2003), a high share of women in government (e.g., Dollar et al., 2001; Swamy et al., 2001) and a history of openness to trade (e.g., Treisman, 2000).

More recently, doubts have surfaced regarding the reliability of these aggregate perception indices; several researchers have found that perceived corruption does not correlate highly with citizens’ actual experiences with corruption based on micro-surveys of individuals. For example, Svensson (2005) found that in regressions using the incidence of bribes as the dependent variable that the coefficient on log GDP per capita is highly significant while the corruption indicators are insignificantly different from zero. Razafindrakoto and Roubaud (2010) 
combine population and expert opinion surveys in a mirror survey in eight sub-Saharan African countries and find that experts do not provide a good gauge of the real level of petty bureaucratic corruption and instead tend to systematically overestimate the extent of corruption. Olken (2009) finds using Indonesian data that the magnitude of the correlation between reported corruption perceptions and actual missing expenditures in the project is small. According to Treisman (2007), it is possible that the experience-based measures are noisier and less reliable or are measuring a different phenomenon, capturing not observations of the frequency of corruption but inferences made by experts and survey respondents on the basis of conventional understandings of corruption's causes.

With the availability of micro-level surveys that feature questions on offering or accepting bribes and on the acceptability or justifiability of various dishonest or illegal behaviors, several researchers have turned to using survey data to examining cross-country differences in corruption. For example, in analyzing gender differences in corruption, Swamy et al. (2001) use the response to the statement "someone accepting a bribe in the course of their duties” from the World Values Survey as their main measure of corruption. This measure is scored on a 1-10 scale where 1 indicates that the behavior can "never be justified" and 10 indicates that the behavior can "always be justified." Similarly, in their analysis of whether corruption is influenced by the perceived activities of others, Dong et al. (2012) use the justifiability of corruption from the European Values Survey and the World Values Survey as their measure of corruption.

This paper aims to make two contributions to the economics literature on corruption. The first contribution of the paper is that it uses micro-level data to focus on two specific issues that may have an impact on one's attitudes towards corruption - risk tolerance and gender roles. The second contribution of this paper is based on exploiting the fact that there are likely to be common unobservable factors affecting the probability of being asked for a bribe, the probability of offering a bribe, and one's view on the justifiability of bribery. By accounting for any intrinsic correlations across the three bribery outcomes and exploiting the time ordering of information contained in these questions, we are able to compute various conditional probabilities of interest. By taking the differences in relevant predicted probabilities, we will be able to generate "treatment effects” to gain insights on, for example, how past experiences with bribery have an 
effect one's current views on bribery. To our knowledge, this is the first empirical paper in the economics literature on corruption to examine the impact of past corruption.

\section{What do Aggregate Corruption Perception Indices Measure?}

In this section, we first examine more closely how the three bribery measures are related to several of the widely used aggregate corruption perception indices. ${ }^{1}$ The main purpose of doing so is to better understand the overlap between our survey-based measures collected at the individual level and the aggregate indices and to determine if they are measuring the same underlying constructs. This will help relate our work to the large corruption literature in economics that is based on these aggregate indices.

The simple correlations between the country averages from each data set and each of the aggregate corruption indices (TI, WB, and ICRG) are then presented in Table 1. The correlations are based on matching the year of the survey to the closest available year of the aggregate corruption index. In general, the correlations between bribe justification and the aggregate corruption indices are quite low, with values ranging from 0.1 to 0.4 . This is fairly consistent across the different datasets. On the other hand, the aggregate corruption indices are quite highly correlated with the country averages in the case of two other bribery outcomes - asked for a bribe and perceived overall corruption - with correlations generally in the 0.7 to 0.8 range. The correlations depicted in the first two rows of Table 1 corroborate that reported in Mocan (2008). Turning to the only available country-level measure of whether a bribe is offered that we are aware of (created based on survey data in round 2 of the European Social Survey), we can see that this measure of corruption is highly correlated with all three aggregate corruption indices, having a correlation of 0.832 with the TI index, 0.773 with the WB index and 0.713 with the ICRG index. In summary, we find that the aggregate corruption indices and the hypothetical question on bribe justification measure rather different constructs. The indices, however, display strong associations with survey based questions on having been asked for a bribe and offered a bribe in the past five years.

\footnotetext{
1 These aggregate indices on their own have been shown by various researchers to be highly correlated with each other with correlation coefficients larger than 0.8 (e.g., see Treisman, 2007).
} 


\section{The Micro-Level Determinants of Bribery}

To date, only a limited number of studies have started to investigate the determinants of corruption at the individual level (e.g., Swamy et al., 2001; Svensson, 2003; Torgler and Valev, 2006; Dong and Torgler, 2009; Dong et al. 2012; Guerrero and Rodríguez-Oreggia, 2008; Mocan, 2008; Torgler and Valev 2010). Mocan (2008), for example, finds that highly educated and high-income individuals have higher exposure to being asked for a bribe by a government official, that males are more frequent targets of bribery, and that living in larger cities increases the risk of exposure to bribery. In addition, Dong and Torgler (2009) find that their results clearly indicate that political interest matters; they find that a higher level of political interest is associated with a lower justifiability of corruption and also a lower perceived level of corruption.

\subsection{Data and Outcomes}

For the remainder of our analysis in this paper, we make use of the second round of the European Social Survey (ESS) data (edition 3.2 released on 2 February 2011), which covers 26 nations and 47,537 persons during the period 2004-2006. The hour-long face-to-face interview in the ESS included (amongst others) questions on family, work and well-being, health and economic morality. We focus on using data from the second round because it includes three key questions on bribery.

The first question on bribery is whether they were asked for a bribe ("How often, if ever, have each of these things happened to you in the last five years? A public official asked you for a favour or a bribe in return for a service?”). The second is whether they have offered a bribe themselves ("How often, if ever, have you done each of these things in the last five years? How often, if ever, have you offered a favour or bribe to a public official in return for their services?”). For both these questions, the responses were coded as: never $=1$, once $=2$, twice $=$ 3 , three of four times $=4$ and five times or more $=5$. An important advantage of using the ESS data is that it allows both of these events to be examined empirically from the viewpoint of the survey respondent. The third question is on bribe justification ("How wrong is a public official asking someone for a favour or bribe in return for their services?”), with responses coded as: seriously wrong $=1$, wrong $=2$, a bit wrong $=3$ and not wrong at all $=4$.

In the paper, we recode the bribery variables into binary outcomes for ease of interpretation, where ever asked for bribe $=1$ and never $=0$, ever offered a bribe $=1$ and never $=$ 
0 , and bribe justification $=1$ if seriously wrong and $=0$ otherwise. This allows the coefficients to be interpreted in terms of probabilities rather than a one unit increase in the non-linear response scale. ${ }^{2}$ Based on our dichotomized outcome measures, the majority of individuals - about 67.7 percent - feel that bribery is not justified. A much smaller percentage of individuals have actual experiences with bribery. On average, 5.8 percent have ever been asked for a bribe and 2.5 percent have ever offered a bribe.

The first six columns of Table 2 provide means of the three bribery outcomes broken down by country and gender. Unlike Swamy et al. (2001) who found that there was a gender gap in bribe justification based on the 1981 and 1990-91 World Values Survey, with males less likely to feel that bribery is never justified, we find in the 2004-06 ESS data that for almost all countries with the exception of the Netherlands and Poland, there is no gender gap in bribe justification. ${ }^{3}$ On the other hand, we find in about half of the countries examined significant gender differences in the proportion of men and women who are asked for a bribe and who offer a bribe. There is great variability in the probability of being asked for a bribe, with Ukraine having the highest probabilities (29 percent for females and 38 percent for males) and Finland the lowest (1 percent for both females and males). The probability of offering a bribe is very low in several countries (less than 1 percent in Finland, Iceland, Ireland and Switzerland) but is again highest in Ukraine (14 percent for females and 16 percent for males).

Are people less likely to engage in bribery if they think it is wrong? Miller (2006) finds using survey data from the Czech Republic, Slovakia, Bulgaria and Ukraine that both citizens and officials explicitly condemn the use of bribes when asked a hypothetical question. Nonetheless many confess to giving or taking them. Even more confess that they would give them if necessary, or would take them if the opportunity occurred. This is not because their values are irrelevant but because their internal values have to contend against external pressures. In Table 2, we also see examples of this in the ESS data. For example, in the Czech Republic, the majority of both males (76 percent) and females (74 percent) feel that bribery is not justified. Yet, a significant proportion of Czechs either give or take bribes. On the other hand, in France, a

\footnotetext{
${ }^{2}$ As a robustness check, we also estimated the results using the original form of the outcomes using OLS and an ordered probit model. The significance and signs of the coefficients of interest remain unchanged (results are available on request).

${ }^{3}$ Torgler and Valev (2010) using the World Values Survey and European Values Survey covering eight Western European countries (France, Great Britain, Italy, The Netherlands, Denmark, Belgium, Ireland, and Spain) spanning the period from 1981 to 1999 also find that women are significantly less likely to agree that corruption can be justified.
} 
lower proportion of males (50 percent) and females (51 percent) hold the view that bribery is not justified but yet, the incidence of bribery in France is relatively lower. It is therefore of interest how these cultures of corruption within a country arise, which is an aim of the literature on the micro-level determinants of corruption.

\subsection{Covariates}

There are standard demographic measures for each survey respondent (e.g., age, years of schooling, gender, marital status etc.) we use as covariates in our econometric model. Subjective values with regards to political interest, trust and materialism for each respondent in each of the 26 countries are also used as covariates in our analysis (Dong and Torgler, 2009; Torgler and Valev, 2010; Guerrero and Rodríguez-Oreggia, 2008). Descriptive statistics of the covariates contained in the ESS data which we use in our analysis are provided in Table 3.

To better understand the social psychology of corruption or how corruption (or lack of corruption) becomes the norm, there is a need to try to understand the process by which people feel more or less comfortable about engaging in corruption and the factors involved. In general, the role of various aspects of culture has been neglected in the corruption literature. This neglect seems odd given the fact that cultural values have such a significant impact on a wide array of business practices in different countries. Exceptions include the studies by Husted (1999), Davis and Ruhe (2003) and Park (2003). In this paper, we focus on two cultural values that may have an impact on one's attitudes towards corruption - risk tolerance and gender roles.

Becker (1968) noted an important role for risk taking behavior in the supply of offences whether an individual perceives that crime pays is an implication of the attitudes the individual has towards risk and is not directly related to the efficiency of the police or the amount spent on combating crime (see Becker, 1968: 179). An open question is whether measures of risk preferences elicited from surveys are reliable. As highlighted by Hartog et al. (2002), there are many pitfalls, complications and even inconsistencies when attempting to measure risk attitudes. Issues such as sensitivity to framing, elicitation bias and preference reversals might serve to discourage any attempts to measure risk attitudes using a simple question. Of those that have attempted to do so, typically, a simple question on the reservation price of a specified lottery is posed to elicit individual risk attitudes by means of the Arrow-Pratt measure of absolute risk aversion. Dohmen et al. (2011) explore in detail how general questions on the willingness to take 
risk (e.g., "How willing are you to take risks, in general?”) can predict actual risky behaviour in the context of a real-stakes lottery experiment. They find that such a simple qualitative measure can actually generate meaningful measures of risk attitudes. This is important for our purposes because our measure of risk is based on a general question in a survey, although not quite worded in exactly the same way.

We measure a person's propensity for risk based on their views on a hypothetical person who is described as: "He looks for adventures and likes to take risks. He wants to have an exciting life." There are six possible responses. We code "very much like me”, "like me”, “somewhat like me” and "a little like me” as a one and "not like me” and "not like me at all” as a zero. ${ }^{4}$ The gender differences in risk attitudes for each country based on this measure are highlighted in Table 2 (columns 7 and 8). In all countries, males show a higher preference for risk as compared to females. There is not much empirical work we are aware of analyzing risk preferences and corruption. Dong et al. (2012) use data from the European Values Survey (EVS) and information regarding a preference for "a safe job with no risk of closing down or unemployment” as their measure of risk aversion. They find that risk averse people are less likely to justify corruption.

With regards to gender and corruption, a belief that females are less susceptible to corruption than males is supported by previous findings in business ethics (e.g., Ford and Richardson, 1994) and psychology (e.g., Eagly and Crowley, 1986). According to Hofstede (1997), societies that are characterized as masculine encourage individuals, especially males, to be ambitious, competitive and to strive for material success. These factors may contribute significantly to one's engagement in unethical behavior. There exists considerable evidence for the existence of a gender gap in competitiveness in the economics literature, with males being found to be more competitive than females (e.g., Niederle and Vesterlund, 2007). Although it has been conventional to think that competition by lowering rents that can be illegally appropriated may lead to lower corruption, Shleifer (2004) suggests that competition may favor unethical behavior such as corruption or cheating.

\footnotetext{
${ }^{4}$ It is common to view risk taking as a single trait in the economics literature. However, as individuals are unlikely to be consistently risk seeking across different domains (Weber et al. 2002), it is possible we are not capturing the appropriate measure of risk preference relevant for corruption. For example, when comparing Chinese and American risk preferences in investment, medical and academic decisions, Hsee and Weber (1999) found that Chinese were more risk seeking but only in the investment domain.
} 
Following the publication of two studies in 2001 (Dollar et al., 2001; Swamy et al., 2001), international development agencies started actively promoting the view that integrating women into the public realm could be a viable anti-corruption tool as women tend to be less corrupt than men. Based on regression modeling of country-level panel data, Dollar et al. (2001) had found that an increase in female representation in parliament would have a significant impact in reducing corruption. On the other hand, Swamy et al. (2001) used micro-level data and also found a similar link between gender and corruption. Using data from the World Values Survey, Swamy et al. (2001) found that women were more likely than men to condemn bribe-taking; based on a survey of business enterprises in Georgia, it was found that female business owners were less likely to offer a bribe compared to male owners. However, these results have been subject to criticisms. Alhassan-Alolo (2007) finds using data on hypothetical scenarios that females did not exude higher ethical standards than men and argues that women may not necessarily prove to be less corrupt than men when exposed to environments characterized by corrupt opportunities and networks. A similar argument can be found in Goetz (2007).

As survey responses may not reflect true behaviour in actual corrupt scenarios, economic decision-making experiments have been used to address this issue. The experimental evidence suggests that women are less likely to offer a bribe or deceive others for personal benefit, which in part may be due to women being more risk averse and having an increased fear of punishment when there is a risk of getting caught (e.g., Schulze and Frank, 2003; Dreber and Johannesson, 2008; Rivas, 2011). Based on his review of survey based and experimental evidence on gender and corruption, Chaudhuri (2012) concludes that there is enough reason to be cautiously optimistic that increasing female participation in all levels of government and bureaucracy can help reduce corruption.

In this paper, we add further to the survey based evidence on gender and corruption for three bribery outcomes using data on gender roles from the ESS. Does a culture of 'masculinity' in a country have an effect on corruption? The perception of gender roles in each country is measured based on summarizing information from three questions in the ESS: (1) Men should have more right to job than women when jobs are scarce; (2) Woman should be prepared to cut down on paid work for sake of family; and (3) Men should take as much responsibility as women for home and children. Responses to all questions are coded as disagree strongly $=1$ to agree strongly $=5$. We reverse code the response to (3) so that agree strongly $=1$ and disagree strongly 
$=5$. This facilitates a common interpretation to all three questions such that a higher value is indicative of a more dominant male role. A 'male role' index is computed as the simple average of the responses to the three questions. ${ }^{5}$ Columns 9 and 10 in Table 2 highlight gender differences in the male role index for each country. Men in Turkey, Italy and Ukraine have the most male dominant views. Interestingly, women in these countries are influenced by the culture in their countries and also tend to think in a similar fashion. For example, if we were to simply compare the absolute values of the male role index, women in Turkey appear to believe more in having a male dominated role than men in Greece, who in their own country are already considered to be relatively male chauvinistic.

There could be much heterogeneity in the data that is not apparent from looking at aggregate country-level data. For example, does it make a difference if the same associations in Figure 1 were to be examined using individual level data rather than aggregate country level data? Research at the individual level typically asks the question, "What characteristics of individuals are determinants of corruption?” On the other hand, research at the country level asks the question, "What characteristics of countries are related to different corruption rates observed across countries?” In reality, although these questions appear to be conceptually similar, they may or may not produce equivalent answers. Sung (2003) raises this issue with regards to the studies by Dollar et al. (2001) and Swamy et al. (2001), which rely on individual-level findings of female honesty to propose hypotheses about groups. He argues that it is not clear whether extrapolating from individual attitudes to group behavior is valid and that it will provide the same results. This is otherwise known as an ecological inference fallacy, whereby a correlation observed at the population level is assumed to apply at the individual level. The problem of aggregation bias is that the pattern of grouping individuals together produces means for the units of analysis that reflect the grouping, not individuals (e.g., see Ostroff, 1993; King, 1997).

In Figure 1, based on our measure of risk, we depict the association between risk taking preference and bribe justification at the country level. It appears that there is a positive association suggesting that risk takers are more likely to view bribery as being seriously wrong. When we later examine the results from the regressions estimated using individual level data for the same set of countries, we will see an example of a sign reversal for the case of the risk variable, where risk takers are instead less likely to view bribery as being seriously wrong.

\footnotetext{
${ }^{5}$ Cronbach's alpha for the male role index we created is 0.517 .
} 
The left panel of Figure 2 depicts the association between country level averages of bribe justification and the male role index. The scatter plot shows quite clearly a negative association between the two variables, suggesting that countries which are more male dominant are less likely to have the view that bribery is seriously wrong. As an alternative measure of gender roles, in the right panel of Figure 2, we use the Gender Gap Index (GGI) from The Global Gender Gap Report 2006 that was created by the World Economic Forum (based on merging publicly available data from international organizations and unique survey data from the World Economic Forum's Executive Opinion Survey) which had the explicit aim of helping to provide a global synopsis of the patterns of gender inequality. It can be seen that with the GGI, where higher scores represent more gender equality, an association also exists between bribe justification and gender roles. ${ }^{6}$ Countries with more gender equality such as Denmark and Norway are more likely to view bribery as seriously wrong.

\section{Results}

\subsection{Univariate Probit Model}

Corruption at the individual level is determined by the expected utility of the individual and can be viewed using the conceptual framework from Becker (1968) that has been applied to participation in other illegal activities. In Becker's model, individuals weigh the expected costs and benefits of their actions and some become criminals "not because their basic motivation differs from other persons but because their benefits and costs differ.” (p. 176). Thus, if performing a corrupt act has high rewards which outweigh the perceived risks of being caught and convicted, an individual will be more likely to engage in corruption.

In this section, we first estimate separate probit models for each of the three corruption outcomes, paying particularly close attention to the influence of gender roles and risk preferences. The probability of the discrete event of offering a bribe can be modelled as a probit relationship:

$$
\mathrm{Offer}_{i}^{*}=X_{i} \beta+\varepsilon_{i}
$$

\footnotetext{
${ }^{6}$ The correlation between our male role index and the World Economic Forum's gender gap index is -0.837 .
} 


$$
\text { Offer }=\left\{\begin{array}{l}
1 \text { if } \text { Offer }_{i}^{*}>0 \\
0 \text { if } O f f e r_{i}^{*} \leq 0
\end{array}\right.
$$

where $X_{i}$ is a vector of personal, demographic and life style attributes for individual $i$. The value of the latent variable Offer ${ }_{i}^{*}$ drives the observed outcome of offering a bribe that takes on the value of one if individual $i$ offers a bribe and zero if $i$ did not offer a bribe. Similarly, the probability of the discrete event of being asked for a bribe and bribe justification can be modelled as $A s k_{i}^{*}=X_{i} \beta+\varepsilon_{i}$ and Justify $y_{i}^{*}=X_{i} \beta+\varepsilon_{i}$ respectively.

In Table 4, we present the coefficients from the univariate probit models which allow for direct comparisons with the coefficients from the multivariate probit models we discuss in the next section. It can be seen that a male dominant role is associated with a lower probability of having the view that bribery is seriously wrong (columns 5 and 6). The corresponding marginal effects for the male role index are -0.025 for males and -0.040 for females. This restates the result we have already seen in Figure 1, with the difference being that now we have also included controls for many different individual characteristics as well as country fixed effects. However, it is interesting that while having a male dominant world view helps shapes one's thinking with regards to a hypothetical question on corruption, it is not associated with offering a bribe and is only associated with being asked for a bribe for males. This difference between thinking of and actually performing a deed is an issue worth investigating further as it might shed light on how social psychology and social norms eventually become translated into action.

For both males and females, we find that risk takers are significantly more likely to offer a bribe (marginal effects are 0.005 for males and 0.004 for females) and to be asked for a bribe (marginal effects are 0.011 for males and 0.011 for females). They are also less likely to view bribery as being seriously wrong (marginal effects are -0.032 for males and -0.037 for females). This is an example of a sign reversal comparing individual and aggregate level analysis discussed earlier and illustrates the danger of making policy inferences solely based on aggregate level data. In our case, risk averse individuals in the majority of each country we examine are more likely to view bribery as being seriously wrong. However, an aggregate comparison of average values of risk preferences and bribe justification across countries leads to the opposite finding. This is because some countries with low average values of risk aversion have high 
average values of bribe justification (viewing it as seriously wrong) even though it is the case that within those countries, risk averse individuals are more likely to view bribery as being seriously wrong.

The desire and importance of being rich appears to also be somewhat important but less so. It is associated with being more likely to offer a bribe (for males), being more likely to be asked for a bribe (for females) and being less likely to view bribery as being seriously wrong (for females).

Among the other control variables, there are several findings of interest. Having trust in the legal system is also associated with a lower probability of being asked for a bribe, likely reflecting an individual's known propensity to seek law enforcement if approached for a bribe. Having more education and an interest in politics is associated with an increase in the probability that one feels that bribery is not justified, consistent with the findings in Truex (2011), who focuses on the role of education for potentially reducing corruption, and Dong and Torgler (2009) who focus on whether political interest affects corruption. For females, regarding people as being fair and having the viewpoint that government should help reduce inequality is associated with a significant lower probability of offering a bribe. Interestingly, women who are more interested in politics are more likely to offer a bribe. We speculate that this perhaps reflects their struggle to obtain equality in what is generally regarded as a male dominated profession.

\subsection{Seemingly Unrelated Probit Model}

There is a potential bias in the univariate probit estimates due to the likely overlap in unobserved characteristics that determine the act of offering a bribe, being asked for a bribe and the likelihood that one views bribery as being seriously wrong. This implies that more efficient estimates can be obtained by allowing for a correlation between the unobserved factors affecting related corruption measures. This study seeks to understand the relationship between the act of offering a bribe, being asked for a bribe, and whether one views bribery as being justifiable without imposing assumptions on the direction of the possible relationships between them. We use a seemingly unrelated regression (SUR) approach to model jointly corruption behaviour. Our use of a SUR probit to analyse joint corruption outcomes measured at the micro-level is novel to this literature. We argue that this is a very appropriate approach as it is very likely that there are 
unobservables affecting related corruption measures that are correlated with each other. ${ }^{7} \mathrm{By}$ exploiting the various joint, marginal and conditional probabilities via the multivariate distribution of the error term across outcomes, this section provides estimates of some "treatment effects" that are policy relevant. For example, the SUR model allows estimation of probabilities of bribe justification conditional on being asked for a bribe. By comparing the two conditional probabilities (having been asked and not been asked for a bribe), we are able to get an estimate of how past corruption experiences are related to one's current views on corruption, or in other words, how contagious corruption can be.

Assuming that there are common factors in the unobservables affecting all three bribery outcomes, the SUR probit model is specified as:

$$
\begin{aligned}
\text { Ask }_{i}^{*} & =X_{i} \beta_{1}+\varepsilon_{1 i} \\
\text { Offer }_{i}^{*} & =X_{i} \beta_{2}+\varepsilon_{2 i} \\
\text { Justify }_{i}^{*} & =X_{i} \beta_{3}+\varepsilon_{3 i}
\end{aligned}
$$

Unlike many applications of the SUR probit model found in the applied literature, we do not have a recursive structure in the model that we employ. This is because of the constraints we have in using the information contained in the three bribery questions in the ESS and the time ordering of events they represent. The question on bribe justification measures current views on bribery, whereas the questions on having been asked for a bribe and offered a bribe are retrospective. Hence, for example, although we would be interested in estimating a model where offering a bribe is a function of bribe justification, we are unable to do so in our data. Despite the shortcomings of our data, even if the set of covariates used in each of the three equations is the same, such a model is still identified through the joint normality of the error terms.

Economists have developed theoretical frameworks to help explain why there might exist large and persistent differences in corruption across comparable countries. For example, Sah (2007) develops a dynamic overlapping generations model whereby an individual's perceptions of his environment are influenced by the realities of the past. At the start, there are a new cohort of citizens and bureaucrats who have diverse initial perceptions concerning corruption becomes active in the economy in each time period. The diversity of initial beliefs can arise from a variety

\footnotetext{
${ }^{7}$ We use the Stata program mvprobit.ado written by Cappellari and Jenkins (2003) to perform our estimations.
} 
of sources, including intrinsic characteristics of individuals, as well as familial and social influences during childhood. Based on his current perceptions and on other considerations, a citizen chooses, in each period, whether or not to cheat, and a bureaucrat chooses whether or not to be corrupt. These choices, in turn, influence the future perceptions of individuals, which influence their future choices. Through these dynamic relationships, future levels of cheating and corruption in the economy become explicitly linked to past levels of cheating and corruption.

Therefore, we would expect that the culture of bribery in the country (e.g., as reflected by the probability that one is asked for a bribe before by a public official) affects one's current view and justification of bribery. In the context of corruption, there might be contagion effects in corruption as if corruption is very prevalent within a society, citizens will feel less guilt when engaging in illegal activities. Dong et al. (2012) use the 'perceived share of compatriots accepting a bribe' in an attempt to empirically quantify the magnitude of such contagion effects. They find that if perceived corruption rises by one unit $(1=$ almost none, $4=$ almost all $)$, the percentage of persons reporting that corruption is never justified falls between 3.8 and 5.1 percentage points.

We also attempt to provide estimates of the contagion effects of corruption in this paper. An advantage of the SUR probit approach is that various conditional probabilities can be predicted for any individual based on the assumption that the error terms follow a multivariate normal distribution. As illustrated in Zhang et al. (2009) in a health economics context, such conditional probabilities allow the estimation of various "treatment effects" and provide a rich source of information for deriving any relevant policy measures.

One possible treatment effect of interest is the effect of having extensive experience with bribery. These are individuals who have both been asked for and offered a bribe in the past five years and provide an upper bound estimate of how experience with bribery affects one's view on bribery:

$$
\begin{aligned}
\tau_{1}= & \operatorname{Pr}(\text { bribe not justified } \mid \text { asked for bribe }=1 \text {, offered bribe }=1)- \\
& \operatorname{Pr}(\text { bribe not justified } \mid \text { asked for bribe }=0 \text {, offered bribe }=0)
\end{aligned}
$$


A second treatment effect of interest is to focus on how being asked for a bribe is related to one's view on bribery. This can be estimated as the difference in the predicted conditional probabilities of bribe justification with and without having been asked for a bribe:

$$
\begin{aligned}
\tau_{2}= & \operatorname{Pr}(\text { bribe not justified } \mid \text { asked for bribe }=1)- \\
& \operatorname{Pr}(\text { bribe not justified } \mid \text { asked for bribe }=0)
\end{aligned}
$$

As we also expect the act of offering a bribe to be affected by the culture of bribery in the country, another relevant treatment effect is:

$$
\tau_{3}=\operatorname{Pr}(\text { offer bribe } \mid \text { asked for bribe }=1)-\operatorname{Pr}(\text { offer bribe } \mid \text { asked for bribe }=0)
$$

Finally, we would also expect the act of offering a bribe to be affected by one's justification of the act. Unfortunately, as discussed above, the informational content in these two questions on bribery in the ESS are not sorted correctly in terms of the time ordering of events and therefore not ideal for estimating this other relevant treatment effect:

$$
\tau_{4}=\operatorname{Pr}(\text { offer bribe } \mid \text { bribe not justified }=1)-\operatorname{Pr}(\text { offer bribe } \mid \text { bribe not justified }=0)
$$

It is worth noting that although equations (3) to (6) resemble causal effects using the potential outcomes notation in the evaluation literature, the assumptions underlying the estimated treatment effects in this paper are quite different then the assumptions from a model based on matching or instrumental variables. Identification in our model is based on joint normality of the error terms which is admittedly a strong assumption. Nevertheless, in the absence of reliable exclusion restrictions, the opportunity to examine interesting conditional probabilities and differences between them to estimate counterfactuals using a SUR model is a useful exercise.

For the SUR probit model in equation (2), as shown in Table 5, the relationship between the unobservables for offering a bribe and being asked for a bribe is highly significant and positive ( $\rho=0.669$ for males and $\rho=0.620$ for females). This indicates that there still remains significant correlations between having been asked for a bribe and offering a bribe even after 
controlling for a rich set of observable individual characteristics. For example, there could be some urgent life situations which make it necessary to both offer or be asked for a bribe.

On the other hand, for both males and females, the unobserved heterogeneity in asking for a bribe and offering a bribe is negatively associated with the unobserved influences on the likelihood of regarding bribery as being not justified. It therefore appears that there are some unobserved factors that make it more likely that bribery is deemed as acceptable and to engage in it (e.g., culture of bribery).

In general, even though there is evidence that the unobservables affecting the three corruption measures are correlated with each other, as can be seen from comparing the probit coefficients in Tables 4 and 5, the results of the SUR model echo the results for the univariate probit models we have already discussed.

Table 6 first presents various conditional probabilities predicted at the sample means for all covariates. These conditional probabilities are then used to estimate the treatment effects corresponding to equations (3) to (6), where the standard errors are computed using a bootstrap with 50 replications. For males, the predicted probability of viewing bribery as being not justified for those with no exposure to bribery experiences is 0.7088 , but this decreases to 0.5971 when a person has been asked for a bribe and offered a bribe before, giving rise to an average treatment effect of $\tau_{1}=-0.1171$. This is nearly significant at the 10 percent level. The corresponding treatment effect for females is $\tau_{1}=-0.1557$ which is significant at the 10 percent level.

Focusing only on the experience of being asked for a bribe in the past, the average treatment effect for males of being asked for a bribe on bribe justification $\left(\tau_{2}\right)$ is -0.089 and 0.079 for females. Both these effects are statistically significant. This implies that past exposure to bribery affects how one currently views bribery, consistent with the theoretical setup that is used in Sah (2007).

The next relevant treatment effect is whether the act of offering a bribe is affected by the culture of bribery in the country $\left(\tau_{3}\right)$. For males (females), the predicted probability of offering a bribe for those who have not been asked for a bribe in the past 5 years is 0.0129 (0.0107), but this increases dramatically to $0.181(0.123)$ when a person has been asked for a bribe before. The estimated average treatment effects are 0.168 for males and 0.113 for females, which are again both statistically significant. 
Finally, although we are very interested in determining how the act of offering a bribe is influenced by one's view of bribery, unfortunately, our data does not allow us to obtain reliable estimates of this treatment effect. In Table 6, we also present estimates of $\tau_{4}$ for completeness where it can be seen that the effects are in the expected direction - individuals who view bribery as wrong are less likely to offer bribes. However, because the assumption that one's view on bribery is time invariant is not tenable (as we saw in estimating $\tau_{1}$ and $\tau_{2}$ ), these effects are not likely to be reliable.

\section{Conclusion}

In exploring the micro-level determinants of corruption, we find that risk is significantly related to the three corruption outcomes we examine. In particular, the marginal effect of risk taking on bribe justification is about 3-4 percent. More masculine societies also appear to have lower probabilities of viewing bribery as being seriously wrong. Assuming that one's views on corruption make a difference on how one acts, this could lay the groundwork for future corruption behavior. This would imply that there is a stronger role for the government to play in punishing or restricting excessive risk taking by individuals as there would be indirect effects on corruption. Promoting more gender equality might also lead to less competitive behavior which has been shown to be related to corrupt behavior.

This paper also provides empirical estimates of how contagious corruption can be, such as the process outlined in Sah's (2007) theoretical model. Past experiences with corruption affects both how bribery is viewed and the actual act of offering a bribe, stressing the importance of implementing direct anti-corruption measures to prevent a multiplier effect from occurring.

Our main empirical analysis is based on the European Social Survey. We suggest that this data set could be used as more of a resource for researchers working on corruption in the future as it offers different alternative measures of corruption. A particular strength of the data set is that it allows researchers the ability to work on corruption as a multi-dimensional construct and not simply from the traditional perspective of whether a bureaucrat has misused public office for private gain.

For future work, it would be useful if micro-level panel data on bribery could be collected and analyzed. We are not aware of any such data sets that exist at present. This would be helpful in improving identification in an empirical model of corruption (e.g., offering a bribe today is a 
function of what your views on bribe justification were in the past and whether you were asked for a bribe in the past) and allow us to better understand the contagion effects of corruption. 


\section{References}

Alhassan-Alolo, N. (2007). Gender and corruption: testing the new consensus. Public Administration and Development, 27, 227-237.

Banerjee, A., S. Mullainathan \& R. Hanna. (2012). Corruption. NBER Working Paper No. 17968.

Becker, G. (1968). Crime and punishment: an economic approach. Journal of Political Economy 76, 169-217.

Brunetti, A. \& B. Weder . (2003). A free press is bad news for corruption, Journal of Public Economics, 87, 1801-24.

Cappellari, L. \& S. Jenkins. (2003). Multivariate probit regression using simulated maximum likelihood. Stata Journal, 3, 278-294.

Chaudhuri, A. (2012). Gender and corruption: a survey of the experimental evidence, Chapter 2, pp. 13-49 in Serra, D. \& L. Wantchekon (eds.), Research in Experimental Economics, Vol. 15: New Advances in Experimental Research on Corruption, Bingley, UK: Emerald Publications.

Davis, J. \& J. Ruhe. (2003). Perceptions of country corruption: antecedents and outcomes. Journal of Business Ethics, 43, 275-88.

Dohmen, T., A. Falk, D. Huffman, U. Sunde, J. Schupp \& G. Wagner. (2011). Individual risk attitudes: measurement, determinants, and behavioral consequences. Journal of the European Economic Association, 9, 522-550.

Dollar, D., R. Fisman \& R. Gatti. (2001). Are women really the 'fairer' sex? Corruption and women in government. Journal of Economic Behavior and Organization, 46, 423-29.

Dong, B., U. Dulleck \& B. Torgler. (2012). Conditional corruption. Journal of Economic Psychology, 33, 609-627.

Dong, B. \& B. Torgler. (2009). Corruption and political interest: empirical evidence at the micro level. Journal of Interdisciplinary Economics, 21, 295-326.

Dreber, A., \& M. Johannesson. (2008). Gender differences in deception. Economics Letters, 99, 197-199.

Eagly, A., \& M. Crowley. (1986). Gender and helping behavior: A meta-analytic review of the social psychological literature. Psychological Bulletin, 100, 283-308.

Fisman, R. \& R. Gatti. (2002). Decentralization and corruption: evidence across countries. Journal of Public Economics, 83, 325 -345. 
Ford, R. \& W. Richardson. (1994). Ethical decision making: a review of the empirical literature. Journal of Business Ethics, 13, 205-221.

Goetz, A. M. (2007). Political cleaners: Women as the new anti-corruption force? Development and Change, 38, 87-105.

Guerrero, M. \& E. Rodríguez-Oreggia. (2008). On the individual decisions to commit corruption: A methodological complement. Journal of Economic Behavior and Organization, 65, 357-372.

Hartog, J., A. Ferrer-i-Carbonell \& N. Jonker. (2002). Linking measured risk aversion to individual characteristics, Kyklos, 55, 3-26.

Hofstede, G. (1997). Cultures and organizations: Software of the mind. New York, NY: McGraw Hill.

Hsee, C. \& E. Weber. (1999). Cross-national differences in risk preference and lay predictions. Journal of Behavioral Decision Making, 12, 165-179.

Husted, B. (1999). Wealth, culture, and corruption. Journal of International Business Studies, 30, 339-60.

King, G. (1997). A Solution to the Ecological Inference Problem: Reconstructing Individual Behavior from Aggregate Data. Princeton: Princeton University Press.

Lambsdorff, J. (2006). Causes and consequences of corruption: what do we know from a crosssection of countries? In: Rose-Ackerman, S. (Ed.), International Handbook on the Economics of Corruption. Edward Elgar, Cheltenham, UK, 3-51.

Mauro, P. (1995). Corruption and growth. Quarterly Journal of Economics, 110: 681-712.

Miller, W. (2006). Corruption and corruptibility. World Development, 34, 371-380.

Mocan, N. (2008). What determines corruption? International evidence from microdata. Economic Inquiry, 46, 493-510.

Niederle, M. \& L. Vesterlund. (2007). Do women shy away from competition? Do men compete too much? Quarterly Journal of Economics, 122, 1067-1102.

Olken, B. (2009). Corruption perceptions vs. corruption reality. Journal of Public Economics, 93, 950-964.

Ostroff, C. (1993). Comparing correlations based on individual-level and aggregated data. Journal of Applied Psychology, 78, 569-582. 
Park, H. (2003). Determinants of corruption: a cross-national analysis. The Multinational Business Review, 11, 29-48.

Razafindrakoto, M., \& F. Roubaud. (2010). Are international databases on corruption reliable? A comparison of expert opinion surveys and household surveys in sub-Saharan Africa. World Development, 38, 1057-1069.

Rivas, M. (2011). An experiment on corruption and gender. Working Paper. Middle East Technical University - Northern Cyprus Campus, Turkey.

Sah, R. (2007). Corruption across countries and regions: some consequences of local osmosis. Journal of Economic Dynamics and Control, 31, 2573-2598.

Schulze, G., \& B. Frank. (2003). Deterrence versus intrinsic motivation: Experimental evidence on the determinants of corruptibility. Economics of Governance, 4, 143-160.

Shleifer, A. (2004). Does competition destroy ethical behavior? American Economic Review, 94, 414-418.

Svensson, J. (2003). Who must pay bribes and how much? Evidence from a cross section of firms. Quarterly Journal of Economics, 118, 207-230.

Svensson, J. (2005). Eight questions about corruption. Journal of Economic Perspectives, 19, 1942.

Sung, H. (2003). Fairer sex or fairer system? Gender and corruption revisited, Social Forces, 82, 703-723.

Swamy, A., S. Knack, Y. Lee \& O. Azfar. (2001). Gender and corruption. Journal of Development Economics, 64, 25-55.

Torgler, B. \& N. Valev. (2006). Corruption and age. Journal of Bioeconomics, 8, 133-145.

Torgler, B. \& N. Valev. (2010). Gender and public attitude toward corruption and tax evasion. Contemporary Economic Policy, 28, 554-568.

Treisman, D. (2000). The causes of corruption: a cross-national study. Journal of Public Economics, 76, 399-457.

Treisman, D. (2007). What have we learned about the causes of corruption from ten years of cross-national empirical research? Annual Review of Political Science, 10, 211-244.

Truex, R. (2011). Corruption, attitudes, and education: survey evidence from Nepal. World Development, 39, 1133-1142. 
Weber, E., A. Blais \& N. Betz. (2002). A domain-specific risk-attitude scale: measuring risk perceptions and risk behaviors. Journal of Behavioral Decision Making, 15, 263-290.

Zhang, X., X. Zhao \& A. Harris. (2009). Chronic diseases and labour force participation in Australia. Journal of Health Economics, 28, 91-108. 
Table 1: Correlations between Bribery Indicators from Survey Data and General Corruption Indices

\begin{tabular}{llccc}
\hline Variable & Dataset & TI & WB & ICRG \\
\hline Asked for bribe & ICVS 1 & 0.818 & 0.787 & 0.658 \\
Asked for bribe & ICVS 2 & 0.769 & 0.644 & 0.637 \\
Perceived overall corruption & ICVS 2 & 0.258 & 0.320 & 0.197 \\
Perceived overall corruption & WVS 3 & 0.897 & 0.837 & 0.832 \\
Bribe justified & WVS 1 & 0.338 & 0.347 & 0.368 \\
Bribe justified & WVS 2 & 0.121 & 0.189 & 0.182 \\
Bribe justified & WVS 3 & 0.312 & 0.278 & 0.267 \\
Bribe justified & WVS 4 & 0.018 & 0.023 & 0.050 \\
Bribe justified & WVS 5 & 0.270 & 0.263 & 0.293 \\
Perceived overall corruption & EVS 3 & 0.841 & 0.707 & 0.764 \\
Bribe justified & EVS 1 & 0.186 & 0.241 & 0.028 \\
Bribe justified & EVS 2 & 0.399 & 0.402 & 0.294 \\
Bribe justified & EVS 3 & 0.365 & 0.392 & 0.317 \\
Bribe justified & EVS 4 & 0.401 & 0.451 & 0.485 \\
Perceived overall corruption & EB 64.3 & 0.852 & 0.796 & 0.863 \\
Asked for Bribe & EB 64.3 & 0.802 & 0.730 & 0.604 \\
Bribe justified & ESS 2 & 0.374 & 0.282 & 0.366 \\
Asked for bribe & ESS 2 & 0.788 & 0.778 & 0.741 \\
Offered Bribe & ESS 2 & 0.832 & 0.773 & 0.713 \\
Perceived police corruption & ESS 5 & 0.969 & 0.926 & 0.892 \\
Perceived judge corruption & ESS 5 & 0.930 & 0.868 & 0.871 \\
\hline
\end{tabular}

Notes: Each cell presents the correlation between the simple averages in survey responses about corruption and general corruption indices corresponding to the survey period and country. ICVS: International Crime Victimization Survey, WVS: World Values Survey, EVS: European Values Survey, EB: Eurobarometer Survey, ESS: European Social Survey, TI: Transparency International, WB: the World Bank, ICRG: the International Country Risk Guide. 
Table 2: Selected Descriptive Statistics by Country and Gender

\begin{tabular}{|c|c|c|c|c|c|c|c|c|c|c|c|}
\hline \multirow[t]{2}{*}{ Country } & \multirow[t]{2}{*}{$\mathrm{N}$} & \multicolumn{2}{|c|}{ Bribery not justified } & \multicolumn{2}{|c|}{ Asked for Bribe } & \multicolumn{2}{|c|}{ Offered Bribe } & \multicolumn{2}{|c|}{$\begin{array}{c}\text { Important to seek } \\
\text { adventures }\end{array}$} & \multicolumn{2}{|c|}{ Male role index } \\
\hline & & $\begin{array}{c}\text { Female } \\
(1)\end{array}$ & $\begin{array}{l}\text { Male } \\
(2)\end{array}$ & $\begin{array}{c}\text { Female } \\
\text { (3) }\end{array}$ & $\begin{array}{l}\text { Male } \\
(4)\end{array}$ & $\begin{array}{c}\text { Female } \\
(5)\end{array}$ & $\begin{array}{c}\text { Male } \\
(6)\end{array}$ & $\begin{array}{c}\text { Female } \\
(7)\end{array}$ & $\begin{array}{c}\text { Male } \\
(8)\end{array}$ & $\begin{array}{c}\text { Female } \\
(9)\end{array}$ & $\begin{array}{l}\text { Male } \\
(10)\end{array}$ \\
\hline Austria & 2,220 & 0.71 & 0.69 & 0.04 & $0.07^{*}$ & 0.01 & 0.02 & 0.65 & $0.75^{* * *}$ & 2.48 & $2.76^{* * *}$ \\
\hline Belgium & 1,770 & 0.69 & 0.69 & 0.01 & 0.02 & 0.01 & 0.01 & 0.50 & $0.65^{* * *}$ & 2.43 & $2.53^{* * *}$ \\
\hline Czech Republic & 2,713 & 0.76 & 0.74 & 0.12 & 0.13 & 0.06 & $0.09^{* * *}$ & 0.49 & $0.65^{* * *}$ & 2.64 & $2.93^{* * *}$ \\
\hline Denmark & 1,473 & 0.85 & 0.84 & 0.01 & $0.03^{* *}$ & 0.00 & 0.01 & 0.59 & $0.69^{* * *}$ & 1.93 & $2.07^{* * *}$ \\
\hline Estonia & 1,965 & 0.61 & 0.58 & 0.08 & $0.12^{* *}$ & 0.01 & $0.02^{*}$ & 0.45 & $0.58^{* * *}$ & 2.65 & $2.82^{* * *}$ \\
\hline Finland & 2,009 & 0.75 & 0.74 & 0.01 & 0.01 & 0.00 & $0.00^{*}$ & 0.58 & $0.68^{* * *}$ & 2.06 & $2.25^{* * *}$ \\
\hline France & 1,806 & 0.50 & 0.51 & 0.01 & $0.02^{* *}$ & 0.01 & 0.01 & 0.42 & $0.63^{* * *}$ & 2.42 & 2.46 \\
\hline Germany & 2,862 & 0.73 & 0.70 & 0.02 & 0.02 & 0.00 & 0.01 & 0.41 & $0.55^{* * *}$ & 2.48 & $2.72^{* * *}$ \\
\hline Greece & 2,402 & 0.74 & 0.71 & 0.09 & $0.17^{* * *}$ & 0.02 & 0.03 & 0.58 & $0.73^{* * *}$ & 2.69 & $2.99^{* * *}$ \\
\hline Hungary & 1,493 & 0.65 & 0.67 & 0.04 & $0.08^{*}$ & 0.01 & $0.03^{*}$ & 0.47 & $0.61^{* * *}$ & 2.82 & $2.91^{*}$ \\
\hline Iceland & 560 & 0.77 & 0.73 & 0.01 & 0.02 & 0.00 & 0.00 & 0.62 & $0.73^{* *}$ & 2.15 & $2.25^{*}$ \\
\hline Ireland & 2,261 & 0.74 & 0.77 & 0.01 & $0.02^{*}$ & 0.00 & 0.00 & 0.60 & 0.65 & 2.45 & $2.56^{* * *}$ \\
\hline Italy & 746 & 0.75 & 0.73 & 0.05 & 0.05 & 0.02 & $0.01^{*}$ & 0.54 & $0.67^{* * *}$ & 2.86 & $3.09^{* * *}$ \\
\hline Luxembourg & 1,620 & 0.73 & 0.69 & 0.02 & $0.05^{* * *}$ & 0.01 & $0.02^{* *}$ & 0.52 & $0.59^{* *}$ & 2.54 & $2.64^{* *}$ \\
\hline Netherlands & 1,878 & 0.72 & $0.78^{* * *}$ & 0.01 & $0.02^{* *}$ & 0.00 & $0.01^{*}$ & 0.62 & $0.73^{* * *}$ & 2.41 & 2.44 \\
\hline Norway & 1,757 & 0.77 & 0.79 & 0.01 & $0.03^{* *}$ & 0.00 & 0.01 & 0.52 & $0.64^{* * *}$ & 2.09 & $2.23^{* * *}$ \\
\hline Poland & 1,690 & 0.81 & $0.75^{* * *}$ & 0.10 & $0.14^{* *}$ & 0.03 & $0.05^{*}$ & 0.47 & $0.64^{* * *}$ & 2.66 & $2.91^{* * *}$ \\
\hline Portugal & 2,035 & 0.58 & 0.57 & 0.03 & 0.04 & 0.02 & 0.02 & 0.54 & $0.74^{* * *}$ & 2.80 & $2.92^{* * *}$ \\
\hline Slovakia & 1,473 & 0.54 & 0.54 & 0.13 & 0.16 & 0.08 & 0.08 & 0.44 & $0.65^{* * *}$ & 2.59 & $2.77^{* * *}$ \\
\hline Slovenia & 1,432 & 0.65 & 0.66 & 0.03 & 0.04 & 0.01 & $0.02^{* *}$ & 0.52 & $0.61^{* * *}$ & 2.43 & $2.55^{* * *}$ \\
\hline Spain & 1,657 & 0.67 & 0.66 & 0.02 & 0.03 & 0.01 & $0.02^{*}$ & 0.47 & $0.55^{* * *}$ & 2.59 & $2.69^{* *}$ \\
\hline Sweden & 1,934 & 0.75 & 0.73 & 0.01 & 0.02 & 0.00 & $0.01^{*}$ & 0.50 & $0.65^{* * *}$ & 2.04 & $2.13^{* * *}$ \\
\hline Switzerland & 2,138 & 0.66 & 0.67 & 0.01 & $0.02^{*}$ & 0.00 & 0.00 & 0.51 & $0.63^{* * *}$ & 2.74 & 2.77 \\
\hline Turkey & 1,808 & 0.64 & 0.68 & 0.04 & 0.09 & 0.01 & $0.02^{* *}$ & 0.49 & $0.60^{* * *}$ & 3.08 & $3.39^{* * *}$ \\
\hline Ukraine & 1,899 & 0.62 & 0.60 & 0.29 & $0.38^{* * *}$ & 0.14 & 0.16 & 0.39 & $0.49^{* * *}$ & 2.86 & $3.08^{* * *}$ \\
\hline United Kingdom & 1,873 & 0.71 & 0.74 & 0.01 & $0.02^{* *}$ & 0.00 & $0.01^{*}$ & 0.51 & $0.69^{* * *}$ & 2.56 & 2.57 \\
\hline
\end{tabular}

${ }^{*} p<0.10,{ }^{* *} p<0.05,{ }^{* * *} p<0.01$ denotes that the difference in means between genders is statistically significant. The statistics are weighted using the ESS

sampling weights. 
Table 3: Summary Statistics for ESS Round 2

\begin{tabular}{|c|c|c|c|c|}
\hline Variable & Mean & $\begin{array}{c}\text { Standard } \\
\text { Deviation }\end{array}$ & Min & Max \\
\hline Bribery not justified & 0.677 & 0.468 & 0 & 1 \\
\hline Asked for bribe & 0.058 & 0.233 & 0 & 1 \\
\hline Offered Bribe & 0.025 & 0.155 & 0 & 1 \\
\hline Male & 0.468 & 0.499 & 0 & 1 \\
\hline Age/100 & 0.452 & 0.182 & 0.13 & 1.02 \\
\hline Years of schooling & 11.190 & 4.260 & 0 & 44 \\
\hline Married & 0.574 & 0.494 & 0 & 1 \\
\hline Household income & 5.783 & 2.652 & 1 & 12 \\
\hline Home owner & 0.726 & 0.446 & 0 & 1 \\
\hline Feel adequate household income & 0.697 & 0.460 & 0 & 1 \\
\hline Number of people in household & 3.212 & 1.694 & 1 & 18 \\
\hline Immigrant & 0.065 & 0.246 & 0 & 1 \\
\hline Ethnic minority & 0.043 & 0.203 & 0 & 1 \\
\hline In paid work & 0.451 & 0.497 & 0 & 1 \\
\hline Most people can be trusted & 4.522 & 2.476 & 0 & 10 \\
\hline Most people are fair & 5.139 & 2.414 & 0 & 10 \\
\hline How interested in politics & 2.331 & 0.928 & 1 & 4 \\
\hline Left-Right Political Scale & 5.091 & 2.318 & 0 & 10 \\
\hline Religiosity & 5.077 & 2.935 & 0 & 10 \\
\hline Govt should reduce income inequality & 0.728 & 0.445 & 0 & 1 \\
\hline Better if everyone looked after themselves & 0.217 & 0.412 & 0 & 1 \\
\hline Trust in the legal system & 4.999 & 2.685 & 0 & 10 \\
\hline Trust in country's parliament & 4.532 & 2.650 & 0 & 10 \\
\hline Important to be rich & 0.565 & 0.496 & 0 & 1 \\
\hline Important to seek adventures & 0.543 & 0.498 & 0 & 1 \\
\hline Male role index & 2.700 & 0.784 & 1 & 5 \\
\hline Difficult to borrow money & 0.462 & 0.499 & 0 & 1 \\
\hline Member of discriminated group & 0.065 & 0.247 & 0 & 1 \\
\hline City & 0.204 & 0.403 & 0 & 1 \\
\hline Suburb & 0.103 & 0.304 & 0 & 1 \\
\hline Town & 0.343 & 0.475 & 0 & 1 \\
\hline
\end{tabular}

Notes: This table shows the summary statistics of variables for the respondents who were surveyed in round 2 of the European Social Survey covering 26 countries during the time period 2004-2006. The statistics are weighted using the ESS sampling weights. 
Table 4: Determinants of Bribery Outcomes: Univariate Probits by Gender

\begin{tabular}{|c|c|c|c|c|c|c|}
\hline & \multicolumn{2}{|c|}{$\begin{array}{l}\text { Offered } \\
\text { bribe }\end{array}$} & \multicolumn{2}{|c|}{ Asked for bribe } & \multicolumn{2}{|c|}{ Bribery not justified } \\
\hline & $\begin{array}{l}\text { Female } \\
\text { (1) }\end{array}$ & $\begin{array}{l}\text { Male } \\
(2)\end{array}$ & $\begin{array}{l}\text { Female } \\
\text { (3) }\end{array}$ & $\begin{array}{l}\text { Male } \\
\text { (4) }\end{array}$ & $\begin{array}{l}\text { Female } \\
(5)\end{array}$ & $\begin{array}{l}\text { Male } \\
(6)\end{array}$ \\
\hline Male role index & $\begin{array}{l}0.020 \\
(0.62)\end{array}$ & $\begin{array}{l}0.027 \\
(0.41)\end{array}$ & $\begin{array}{l}-0.023 \\
(-0.63)\end{array}$ & $\begin{array}{l}0.091^{* *} \\
(2.33)\end{array}$ & $\begin{array}{c}-0.113^{* * *} \\
(-3.22)\end{array}$ & $\begin{array}{l}-0.070^{*} \\
(-1.89)\end{array}$ \\
\hline $\begin{array}{l}\text { Important to seek } \\
\text { adventures }\end{array}$ & $\begin{array}{l}0.254^{* * * *} \\
(3.53)\end{array}$ & $\begin{array}{c}0.144^{* * * *} \\
(3.67)\end{array}$ & $\begin{array}{c}0.209^{* * *} \\
(4.73)\end{array}$ & $\begin{array}{l}0.144^{* * * *} \\
(3.96)\end{array}$ & $\begin{array}{c}-0.103^{*} \\
(-1.81)\end{array}$ & $\begin{array}{l}-0.091^{* *} \\
(-2.45)\end{array}$ \\
\hline Member of & 0.220 & 0.058 & 0.153 & $0.157^{* *}$ & $0.134^{* *}$ & $0.130^{* *}$ \\
\hline discriminated group & (1.48) & $(0.44)$ & (1.19) & $(2.14)$ & $(2.50)$ & $(2.37)$ \\
\hline Important to be rich & $\begin{array}{l}0.079 \\
(1.42)\end{array}$ & $\begin{array}{c}0.112^{* *} \\
(2.01)\end{array}$ & $\begin{array}{l}0.121^{* *} \\
(2.12)\end{array}$ & $\begin{array}{l}-0.014 \\
(-0.24)\end{array}$ & $\begin{array}{c}-0.096^{* * *} \\
(-2.91)\end{array}$ & $\begin{array}{l}-0.046 \\
(-1.07)\end{array}$ \\
\hline Age/100 & $\begin{array}{l}3.320^{* *} \\
(2.19)\end{array}$ & $\begin{array}{l}-0.125 \\
(-0.10)\end{array}$ & $\begin{array}{l}1.313 \\
(1.14)\end{array}$ & $\begin{array}{l}1.552^{*} \\
(1.82)\end{array}$ & $\begin{array}{l}1.056 \\
(1.36)\end{array}$ & $\begin{array}{c}2.418^{* * *} \\
(4.20)\end{array}$ \\
\hline $\mathrm{Age}^{2} / 100$ & $\begin{array}{c}-383.962^{* * *} \\
(-2.72)\end{array}$ & $\begin{array}{c}-31.161 \\
(-0.22)\end{array}$ & $\begin{array}{c}-198.148^{*} \\
(-1.74)\end{array}$ & $\begin{array}{c}-242.213^{* * *} \\
(-2.73)\end{array}$ & $\begin{array}{c}-73.322 \\
(-0.98)\end{array}$ & $\begin{array}{c}-207.780^{* * *} \\
(-4.17)\end{array}$ \\
\hline Years of schooling & $\begin{array}{l}-0.016 \\
(-0.92)\end{array}$ & $\begin{array}{l}0.003 \\
(0.21)\end{array}$ & $\begin{array}{l}0.000 \\
(0.02)\end{array}$ & $\begin{array}{l}0.000 \\
(0.04)\end{array}$ & $\begin{array}{l}0.017^{* *} \\
(2.58)\end{array}$ & $\begin{array}{c}0.024^{* * *} \\
(3.11)\end{array}$ \\
\hline Married & $\begin{array}{l}0.063^{* *} \\
(2.15)\end{array}$ & $\begin{array}{l}0.016 \\
(0.48)\end{array}$ & $\begin{array}{c}0.100^{* * *} \\
(4.22)\end{array}$ & $\begin{array}{l}0.009 \\
(0.44)\end{array}$ & $\begin{array}{l}-0.005 \\
(-0.20)\end{array}$ & $\begin{array}{l}0.018 \\
(0.64)\end{array}$ \\
\hline Household income & $\begin{array}{l}0.006 \\
(0.30)\end{array}$ & $\begin{array}{l}-0.002 \\
(-0.10)\end{array}$ & $\begin{array}{l}0.025^{*} \\
(1.82)\end{array}$ & $\begin{array}{l}0.010 \\
(0.78)\end{array}$ & $\begin{array}{l}0.014 \\
(1.21)\end{array}$ & $\begin{array}{l}0.005 \\
(0.45)\end{array}$ \\
\hline Home owner & $\begin{array}{c}-0.180^{* * *} \\
(-3.24)\end{array}$ & $\begin{array}{l}-0.032 \\
(-0.62)\end{array}$ & $\begin{array}{c}-0.174^{* * *} \\
(-3.25)\end{array}$ & $\begin{array}{l}0.027 \\
(0.51)\end{array}$ & $\begin{array}{l}0.053 \\
(0.88)\end{array}$ & $\begin{array}{l}0.005 \\
(0.18)\end{array}$ \\
\hline $\begin{array}{l}\text { Feel adequate household } \\
\text { income }\end{array}$ & $\begin{array}{l}-0.010 \\
(-0.18)\end{array}$ & $\begin{array}{l}0.100 \\
(1.10)\end{array}$ & $\begin{array}{c}-0.158^{* *} \\
(-2.26)\end{array}$ & $\begin{array}{l}-0.133 \\
(-1.39)\end{array}$ & $\begin{array}{l}-0.008 \\
(-0.20)\end{array}$ & $\begin{array}{l}-0.009 \\
(-0.21)\end{array}$ \\
\hline $\begin{array}{l}\text { Number of household } \\
\text { members }\end{array}$ & $\begin{array}{l}-0.033^{* *} \\
(-2.29)\end{array}$ & $\begin{array}{l}-0.005 \\
(-0.19)\end{array}$ & $\begin{array}{c}-0.042^{* * *} \\
(-3.05)\end{array}$ & $\begin{array}{l}-0.026^{* *} \\
(-2.36)\end{array}$ & $\begin{array}{l}-0.006 \\
(-0.45)\end{array}$ & $\begin{array}{c}-0.027^{* * *} \\
(-3.51)\end{array}$ \\
\hline Immigrant & $\begin{array}{l}0.200^{* *} \\
(2.16)\end{array}$ & $\begin{array}{l}0.089 \\
(1.02)\end{array}$ & $\begin{array}{l}0.065 \\
(0.81)\end{array}$ & $\begin{array}{l}-0.020 \\
(-0.19)\end{array}$ & $\begin{array}{l}0.024 \\
(0.44)\end{array}$ & $\begin{array}{l}-0.033 \\
(-0.36)\end{array}$ \\
\hline Ethnic minority & $\begin{array}{l}0.044 \\
(0.21)\end{array}$ & $\begin{array}{l}-0.323 \\
(-1.38)\end{array}$ & $\begin{array}{l}0.008 \\
(0.09)\end{array}$ & $\begin{array}{l}0.197 \\
(1.60)\end{array}$ & $\begin{array}{l}-0.086 \\
(-1.32)\end{array}$ & $\begin{array}{l}-0.094^{* *} \\
(-2.07)\end{array}$ \\
\hline In paid work & $\begin{array}{l}-0.050 \\
(-0.74)\end{array}$ & $\begin{array}{l}0.058 \\
(1.31)\end{array}$ & $\begin{array}{l}0.018 \\
(0.99)\end{array}$ & $\begin{array}{l}0.045 \\
(1.56)\end{array}$ & $\begin{array}{l}0.017 \\
(0.89)\end{array}$ & $\begin{array}{l}-0.006 \\
(-0.23)\end{array}$ \\
\hline $\begin{array}{l}\text { Most people can be } \\
\text { trusted }\end{array}$ & $\begin{array}{l}-0.008 \\
(-0.55)\end{array}$ & $\begin{array}{l}0.005 \\
(0.24)\end{array}$ & $\begin{array}{l}0.001 \\
(0.05)\end{array}$ & $\begin{array}{l}-0.007 \\
(-0.80)\end{array}$ & $\begin{array}{l}0.000 \\
(0.02)\end{array}$ & $\begin{array}{l}-0.008 \\
(-1.18)\end{array}$ \\
\hline Most people are fair & $\begin{array}{l}-0.028^{* *} \\
(-2.56)\end{array}$ & $\begin{array}{l}-0.014 \\
(-1.29)\end{array}$ & $\begin{array}{l}-0.020^{*} \\
(-1.81)\end{array}$ & $\begin{array}{c}-0.020^{* * *} \\
(-2.81)\end{array}$ & $\begin{array}{l}-0.010^{*} \\
(-1.82)\end{array}$ & $\begin{array}{c}0.014^{* * *} \\
(2.94)\end{array}$ \\
\hline $\begin{array}{l}\text { How interested in } \\
\text { politics }\end{array}$ & $\begin{array}{l}0.073^{* *} \\
(2.50)\end{array}$ & $\begin{array}{l}-0.014 \\
(-0.31)\end{array}$ & $\begin{array}{l}0.026 \\
(0.69)\end{array}$ & $\begin{array}{l}0.102^{* * * *} \\
(3.81)\end{array}$ & $\begin{array}{l}0.041^{* *} \\
(2.13)\end{array}$ & $\begin{array}{l}0.032^{* *} \\
(2.18)\end{array}$ \\
\hline Left-right political scale & $\begin{array}{l}0.000 \\
(0.01)\end{array}$ & $\begin{array}{l}0.015 \\
(1.42)\end{array}$ & $\begin{array}{l}-0.003 \\
(-0.35)\end{array}$ & $\begin{array}{l}0.018 \\
(1.53)\end{array}$ & $\begin{array}{l}0.003 \\
(0.51)\end{array}$ & $\begin{array}{l}-0.011 \\
(-0.98)\end{array}$ \\
\hline Religiosity & $\begin{array}{l}-0.005 \\
(-0.39)\end{array}$ & $\begin{array}{l}0.018 \\
(0.96)\end{array}$ & $\begin{array}{l}-0.012^{*} \\
(-1.65)\end{array}$ & $\begin{array}{l}-0.013^{*} \\
(-1.74)\end{array}$ & $\begin{array}{l}0.008 \\
(1.32)\end{array}$ & $\begin{array}{l}0.004 \\
(1.15)\end{array}$ \\
\hline $\begin{array}{l}\text { Govt should reduce } \\
\text { income inequality }\end{array}$ & $\begin{array}{c}-0.266^{* * *} \\
(-4.13)\end{array}$ & $\begin{array}{l}-0.108 \\
(-1.56)\end{array}$ & $\begin{array}{c}-0.179^{* * *} \\
(-2.81)\end{array}$ & $\begin{array}{l}-0.073 \\
(-1.60)\end{array}$ & $\begin{array}{l}0.086 \\
(1.62)\end{array}$ & $\begin{array}{l}0.063^{*} \\
(1.83)\end{array}$ \\
\hline $\begin{array}{l}\text { Better if everyone } \\
\text { looked after themselves }\end{array}$ & $\begin{array}{l}0.076 \\
(1.31)\end{array}$ & $\begin{array}{l}-0.007 \\
(-0.08)\end{array}$ & $\begin{array}{l}0.125^{* *} \\
(2.24)\end{array}$ & $\begin{array}{l}0.025 \\
(0.40)\end{array}$ & $\begin{array}{l}-0.116^{* * *} \\
(-2.69)\end{array}$ & $\begin{array}{c}-0.137^{* * *} \\
(-2.93)\end{array}$ \\
\hline Trust in the legal system & $\begin{array}{l}-0.021 \\
(-1.30)\end{array}$ & $\begin{array}{l}-0.008 \\
(-0.54)\end{array}$ & $\begin{array}{c}-0.046^{* * *} \\
(-3.36)\end{array}$ & $\begin{array}{l}-0.025^{* *} \\
(-2.22)\end{array}$ & $\begin{array}{l}0.012^{* *} \\
(2.42)\end{array}$ & $\begin{array}{l}0.007 \\
(1.08)\end{array}$ \\
\hline $\begin{array}{l}\text { Trust in country's } \\
\text { parliament }\end{array}$ & $\begin{array}{l}0.002 \\
(0.22)\end{array}$ & $\begin{array}{l}-0.030^{*} \\
(-1.74)\end{array}$ & $\begin{array}{l}0.002 \\
(0.13)\end{array}$ & $\begin{array}{l}-0.017^{* *} \\
(-2.33)\end{array}$ & $\begin{array}{l}-0.006 \\
(-1.29)\end{array}$ & $\begin{array}{l}0.005 \\
(0.94)\end{array}$ \\
\hline
\end{tabular}




\begin{tabular}{lcccccc}
\hline City & 0.071 & -0.059 & $0.116^{*}$ & 0.114 & 0.039 & $-0.085^{*}$ \\
& $(0.81)$ & $(-0.81)$ & $(1.83)$ & $(1.37)$ & $(0.83)$ & $(-1.86)$ \\
Suburb & -0.012 & 0.044 & $0.254^{* *}$ & 0.013 & $-0.108^{* * *}$ & $-0.062^{*}$ \\
& $(-0.06)$ & $(0.54)$ & $(2.53)$ & $(0.18)$ & $(-2.67)$ & $(-1.71)$ \\
Town & 0.054 & -0.022 & 0.064 & 0.001 & -0.050 & $-0.083^{* *}$ \\
& $(0.73)$ & $(-0.38)$ & $(1.38)$ & $(0.02)$ & $(-1.22)$ & $(-2.01)$ \\
& & & & & & \\
Pseudo $\mathrm{R}^{2}$ & 0.272 & 0.196 & 0.250 & 0.202 & 0.049 & 0.058 \\
$\mathrm{~N}$ & 24532 & 21477 & 23780 & 20577 & 25512 & 21837 \\
\hline
\end{tabular}

Notes: Coefficients from the probit model are reported. $t$ statistics are presented in parentheses. Robust standard errors are clustered at the country level. ${ }^{*} p<0.10,{ }^{* *} p<0.05,{ }^{* * *} p<0.01$. The statistics are weighted using the ESS sampling weights. 
Table 5: Determinants of Bribery Outcomes: SUR Probit by Gender

\begin{tabular}{|c|c|c|c|c|c|c|}
\hline & \multicolumn{3}{|c|}{ Female } & \multicolumn{3}{|c|}{ Male } \\
\hline & $\begin{array}{c}\text { Offered } \\
\text { Bribe } \\
(1) \\
\end{array}$ & $\begin{array}{c}\text { Asked } \\
\text { for bribe } \\
(2)\end{array}$ & $\begin{array}{c}\text { Bribery } \\
\text { not } \\
\text { justified } \\
(3) \\
\end{array}$ & $\begin{array}{c}\begin{array}{c}\text { Offered } \\
\text { Bribe }\end{array} \\
(4) \\
\end{array}$ & $\begin{array}{c}\text { Asked for } \\
\text { bribe } \\
\text { (5) }\end{array}$ & $\begin{array}{c}\text { Bribery } \\
\text { not } \\
\text { justified } \\
(6) \\
\end{array}$ \\
\hline Male role index & $\begin{array}{l}-0.004 \\
(-0.14)\end{array}$ & $\begin{array}{c}0.004 \\
(0.013)\end{array}$ & $\begin{array}{c}-0.111^{* * *} \\
(-3.09)\end{array}$ & $\begin{array}{l}0.042 \\
(0.58)\end{array}$ & $\begin{array}{l}0.104^{* * *} \\
(2.98)\end{array}$ & $\begin{array}{l}-0.062 \\
(-1.60)\end{array}$ \\
\hline $\begin{array}{l}\text { Important to seek } \\
\text { adventures }\end{array}$ & $\begin{array}{c}0.245^{* * *} \\
(3.06)\end{array}$ & $\begin{array}{c}0.204^{* * *} \\
(4.38)\end{array}$ & $\begin{array}{c}-0.110^{* *} \\
(-2.03)\end{array}$ & $\begin{array}{l}0.111^{* * *} \\
(2.56)\end{array}$ & $\begin{array}{c}0.149^{* * *} \\
(4.07)\end{array}$ & $\begin{array}{l}-0.080^{*} \\
(-1.93)\end{array}$ \\
\hline $\begin{array}{l}\text { Member of discriminated } \\
\text { group }\end{array}$ & $\begin{array}{l}0.218 \\
(1.41)\end{array}$ & $\begin{array}{l}0.135 \\
(1.00)\end{array}$ & $\begin{array}{c}0.138^{* * *} \\
(2.74)\end{array}$ & $\begin{array}{l}0.062 \\
(0.42)\end{array}$ & $\begin{array}{l}0.182^{* *} \\
(2.26)\end{array}$ & $\begin{array}{c}0.141^{* * *} \\
(2.63)\end{array}$ \\
\hline Important to be rich & $\begin{array}{l}0.076 \\
(1.28)\end{array}$ & $\begin{array}{l}0.098^{*} \\
(1.72)\end{array}$ & $\begin{array}{c}-0.081^{* * *} \\
(-2.73)\end{array}$ & $\begin{array}{l}0.139^{* *} \\
(2.07)\end{array}$ & $\begin{array}{l}-0.010 \\
(-0.19)\end{array}$ & $\begin{array}{l}-0.054 \\
(-1.48)\end{array}$ \\
\hline Other covariates in Table 4 & Yes & Yes & Yes & Yes & Yes & Yes \\
\hline$\rho$ (ask and justify) & $\begin{array}{c}-0.090^{* * *} \\
(-3.40)\end{array}$ & & & $\begin{array}{l}-0.108^{* *} \\
(-2.39)\end{array}$ & & \\
\hline$\rho$ (offer and justify) & $\begin{array}{c}-0.175^{* * *} \\
(-3.91)\end{array}$ & & & $\begin{array}{l}-0.097^{* *} \\
(-2.08)\end{array}$ & & \\
\hline$\rho$ (offer and ask) & $\begin{array}{l}0.620^{* * *} \\
(28.04)\end{array}$ & & & $\begin{array}{l}0.669^{* * *} \\
(41.26)\end{array}$ & & \\
\hline $\mathrm{N}$ & 23306 & & & 20234 & & \\
\hline
\end{tabular}

Notes: Selected coefficients from the SUR probit model are reported. ${ }^{*} p<0.10,{ }^{* *} p<0.05,{ }^{* * *} p<0.01$. The number of random variates drawn when calculating the simulated likelihood in the multivariate probit model is 100. 
Table 6: Predicted Probabilities for Bribery

\begin{tabular}{|c|c|c|}
\hline & Male & Female \\
\hline \multicolumn{3}{|l|}{ Marginal probabilities } \\
\hline $\operatorname{Pr}($ asked $=1)$ & $\begin{array}{c}0.066 \\
(0.084)\end{array}$ & $\begin{array}{c}0.047 \\
(0.076)\end{array}$ \\
\hline $\operatorname{Pr}($ offered $=1)$ & $\begin{array}{c}0.027 \\
(0.042)\end{array}$ & $\begin{array}{c}0.020 \\
(0.042)\end{array}$ \\
\hline Pr(bribe not justified=1) & $\begin{array}{c}0.697 \\
(0.123)\end{array}$ & $\begin{array}{c}0.696 \\
(0.110)\end{array}$ \\
\hline \multicolumn{3}{|l|}{ Conditional probabilities } \\
\hline $\operatorname{Pr}($ bribe not justified $\mid$ asked $=1$, offered $=1$ ) & $\begin{array}{c}0.5971 \\
(0.0667)\end{array}$ & $\begin{array}{c}0.5469 \\
(0.0598)\end{array}$ \\
\hline $\operatorname{Pr}($ bribe not justified $\mid$ asked $=0$, offered $=0$ ) & $\begin{array}{c}0.7088 \\
(0.0037)\end{array}$ & $\begin{array}{c}0.7027 \\
(0.0044)\end{array}$ \\
\hline $\operatorname{Pr}($ bribe not justified | asked $=1$ ) & $\begin{array}{l}0.6166 \\
(0.021)\end{array}$ & $\begin{array}{l}0.6209 \\
(0.029)\end{array}$ \\
\hline $\operatorname{Pr}($ bribe not justified $\mid$ asked $=0$ ) & $\begin{array}{c}0.7065 \\
(0.0034)\end{array}$ & $\begin{array}{c}0.7004 \\
(0.0038)\end{array}$ \\
\hline $\operatorname{Pr}($ offer $\mid$ asked=1) & $\begin{array}{c}0.1813 \\
(0.0146)\end{array}$ & $\begin{array}{c}0.1233 \\
(0.0143)\end{array}$ \\
\hline $\operatorname{Pr}($ offer $\mid$ asked=0) & $\begin{array}{c}0.0129 \\
(0.0009)\end{array}$ & $\begin{array}{c}0.0107 \\
(0.0010)\end{array}$ \\
\hline $\operatorname{Pr}($ offer $\mid$ bribe not justified =1) & $\begin{array}{c}0.0232 \\
(0.0015)\end{array}$ & $\begin{array}{c}0.0161 \\
(0.0013)\end{array}$ \\
\hline $\operatorname{Pr}($ offer $\mid$ bribe not justified $=0$ ) & $\begin{array}{c}0.0330 \\
(0.0029) \\
\end{array}$ & $\begin{array}{c}0.0265 \\
(0.0021) \\
\end{array}$ \\
\hline \multicolumn{3}{|l|}{ Treatment effects } \\
\hline $\operatorname{Pr}($ bribe not justified $\mid$ asked $=1$, offered $=1)$ - $\operatorname{Pr}($ bribe not justified $\mid$ asked $=0$, offered $=0$ ) & $\begin{array}{l}-0.1117 \\
(0.0686)\end{array}$ & $\begin{array}{c}-0.1557^{* *} \\
(0.0617)\end{array}$ \\
\hline $\operatorname{Pr}($ bribe not justified $\mid$ asked=1) $-\operatorname{Pr}($ bribe not justified | asked=0) & $\begin{array}{l}-0.089^{* * *} \\
(0.0219)\end{array}$ & $\begin{array}{c}-0.079^{* *} \\
(0.031)\end{array}$ \\
\hline $\operatorname{Pr}($ offer $\mid$ asked=1) $-\operatorname{Pr}($ offer $\mid$ asked=0) & $\begin{array}{l}0.1684^{* * *} \\
(0.0149)\end{array}$ & $\begin{array}{c}0.1127^{* * *} \\
(0.0147)\end{array}$ \\
\hline $\operatorname{Pr}($ offer $\mid$ bribe not justified =1) $-\operatorname{Pr}($ offer $\mid$ bribe not justified =0) & $\begin{array}{c}-0.0098^{* * *} \\
(0.0036) \\
\end{array}$ & $\begin{array}{c}-0.0104^{* * *} \\
(0.0026) \\
\end{array}$ \\
\hline
\end{tabular}

Notes: Predicted probabilities are evaluated at the means of covariates. Standard errors for the conditional probabilities and treatment effects are estimated using bootstraps (replications $=50$ ). Estimated treatment effects are significant at the: ${ }^{* *} 5 \%$ level, ${ }^{* * *} 1 \%$ level. 
Figure 1: Cross-Country Scatter Plots of Bribe Justification with Risk Attitudes

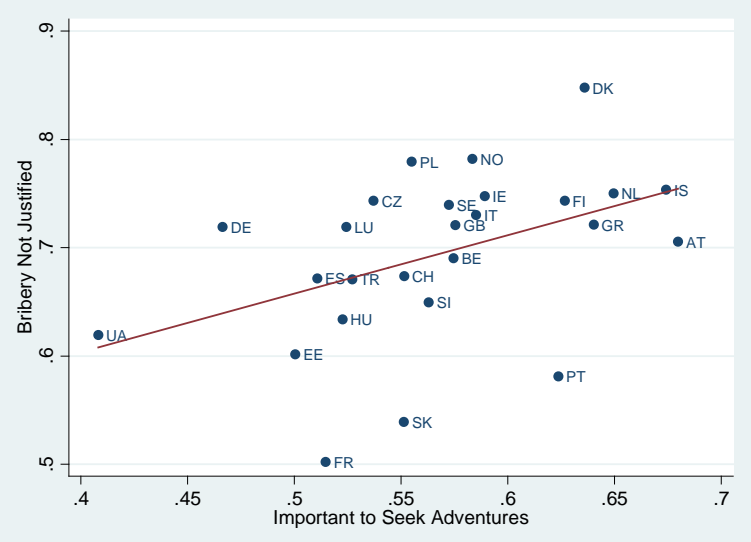

Figure 2: Cross-Country Scatter Plots of Bribe Justification with Gender Roles
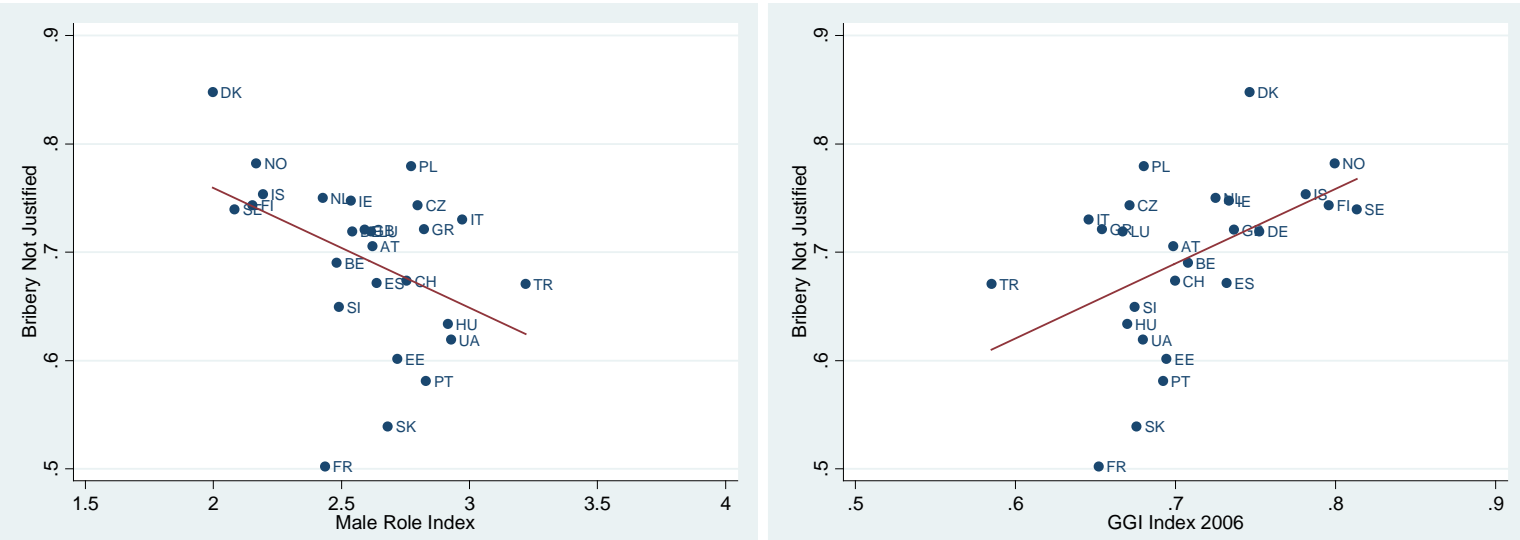


\section{Appendix A}

Definition of Control Variables:

Male: Respondent's gender $(1=$ male, $0=$ female $)$.

Age: Respondent's age in years.

Years of schooling: Respondent's years of education.

Married: Respondent's marital status $(1=$ married, $0=$ separated, divorced, widowed, never married).

Household income: Household's total net income from all sources on a scale of 1-12.

Home owner: Whether dwelling owned by any household member $(1=$ own dwelling, $0=$ does not own dwelling).

Feel adequate household income: Feeling about household's income nowadays $(1=$ very difficult, 2 = difficult, 3 = coping, 4 = living comfortably on present income).

Number of people in household: Number of people regularly living as member of the household.

Immigrant: Whether respondent was born in the country they currently live in $(1=$ immigrant, 0 $=$ not immigrant).

Ethnic minority: Whether respondent belongs to a minority ethnic group in the country they currently live in.

In paid work: Whether respondent was in paid work 7 days prior to the survey interview $(1=$ in paid work, 0 = unemployed, pursuing education, disabled, retired, other)

Most people can be trusted: Most people can be trusted or you can't be too careful? ( 0 = you can't be too careful, $10=$ most people can be trusted).

Most people are fair: Most people try to take advantage of you, or try to be fair? $(0=$ most people try to take advantage of me, $10=$ most people try to be fair).

How interested in politics: How interested would you say you are in politics, are you? $(1=$ not at all interested, 2 = hardly interested, 3 = quite interested, 4 = very interested).

Left-right political scale: Placement on left-right scale in politics $(0=$ extreme left, $\ldots, 10=$ extreme right).

Religiosity: How religious are you? $(0=$ not at all religious, $\ldots, 10=$ very religious $)$. 
Government should reduce income inequality: The government should take measures to reduce differences in income levels ( 1 = agree strongly, agree, $0=$ neither agree nor disagree, disagree, disagree strongly).

Better if everyone looked after themselves: Society would be better off if everyone looked after themselves $(1=$ agree strongly, agree, $0=$ neither agree nor disagree, disagree, disagree strongly).

Trust in the legal system and trust in country's parliament: Please tell me on a score of 0-10 how much you personally trust each of the institutions I read out $(0=$ no trust at all, $\ldots, 10=$ complete trust).

Important to be rich: How much like you is this person? "It is important to him to be rich. He wants to have a lot of money and expensive things." ( 1 = very much like me, like me somewhat, like me, a little like me, $0=$ not like me, not like me at all).

Important to seek adventures: How much like you is this person? "He looks for adventures and likes to take risks. He wants to have an exciting life." ( $1=$ very much like me, like me somewhat, like me, a little like me, $0=$ not like me, not like me at all).

Male role index: Based on summarizing information from three questions in the survey: (1) Men should have more right to job than women when jobs are scarce; (2) Woman should be prepared to cut down on paid work for sake of family; and (3) Men should take as much responsibility as women for home and children. Responses to all questions are coded as disagree strongly $=1$ to agree strongly $=5$. We reverse code the response to (3) so that agree strongly $=1$ and disagree strongly $=5$ and compute the average.

Difficult to borrow money: Whether borrowing money to make ends meet is difficult or easy (1 $=$ very difficult, quite difficult, 0 = neither easy nor difficult, quite easy, very easy).

Member of discriminated group: Whether respondent is a member of a group discriminated against in the country they currently live in $(1=$ yes, $0=$ no $)$.

City: Respondent lives in a big city.

Suburb: Respondent lives in the suburbs or outskirts of a big city.

Town: Respondent lives in a town or small city. 